\title{
Priming of pioneer tree Guazuma ulmifolia (Malvaceae) seeds evaluated by an automated computer image analysis
}

\author{
Pedro Henrique Santin Brancalion ${ }^{1}$; David $\mathrm{Tay}^{3}$; Ana Dionisia da Luz Coelho \\ Novembre $^{2 *}$; Ricardo Ribeiro Rodrigues ${ }^{4}$ Júlio Marcos Filho ${ }^{2}$ \\ ${ }^{1} U S P / E S A L Q$ - Programa de Pós-Graduação em Fitotecnia. \\ ${ }_{3}^{2}$ USP/ESALQ - Depto. de Produção Vegetal, C.P. 09 - 13418-900, Piracicaba, SP - Brasil. \\ ${ }^{3}$ International Potato Center, Apartado 1558 - La Molina, Peru. \\ ${ }^{4}$ USP/ESALQ - Depto. de Ciências Biológicas, C.P. 09 - 13418-900, Piracicaba, SP - Brasil. \\ *Corresponding author< <adlcnove@esalq.usp.br>
}

\begin{abstract}
Direct seeding is one of the most promising methods in restoration ecology, but low field seedling emergence from pioneer tree seeds still reduces its large scale applicability. The aim of this research was to evaluate seed priming for the pioneer tree species Guazuma ulmifolia. Priming treatments were selected based on seed hydration curves in water and in PEG 8000 solution. Seeds were primed in water for 16 $\mathrm{h}$ and in Polyethylene glycol - PEG $8000(-0.8 \mathrm{MPa}$ for 56 and $88 \mathrm{~h})$ at $20^{\circ} \mathrm{C}$ to reach approximately $30 \%$ water content. Half of the seed sample of each treatment was dried back to the initial moisture content (7.2\%); both dried and non-dried primed seeds as well as the unprimed seeds (control) were tested for germination (percentage and rate) and vigor (electrical conductivity of seed leachates). Seedling emergence percentage and rate were evaluated under greenhouse conditions, while seedling length and uniformity of seedling development were estimated using the automated image analysis software SVIS ${ }^{\circledR}$. Primed seeds showed the highest physiological potential, which was mainly demonstrated by image analysis. Fresh or dried primed seeds in water for $16 \mathrm{~h}$ and in PEG (-0.8 MPa) for $56 \mathrm{~h}$, and fresh primed seeds in PEG for $88 \mathrm{~h}$, improved G. ulmifolia germination performance. It is suggested that these treatments were promising to enhance efficiency of stand establishment of this species by direct seeding in restoration ecology programs.
\end{abstract}

Key words: SVIS ${ }^{\circledR}$, forest seeds, seed vigor, restoration ecology, direct seeding

\section{Condicionamento fisiológico de sementes da árvore pioneira Guazuma ulmifolia (Malvaceae) avaliado por análise computadorizada de imagens}

\begin{abstract}
RESUMO: A semeadura direta é um dos métodos mais promissores para a restauração ecológica, mas a baixa emergência de plântulas em campo a partir de sementes de árvores pioneiras ainda limita sua aplicabilidade em larga escala. Avaliou-se a resposta de sementes da espécie florestal pioneira Guazuma ulmifolia ao condicionamento fisiológico. Os tratamentos foram selecionados com base em curvas de hidratação em água e em solução osmótica de Polietilenoglicol - PEG 8000. As sementes foram condicionadas em água por 16 h e em PEG 8000 $(-0,8 \mathrm{MPa}$ por 56 e $88 \mathrm{~h})$ a $20^{\circ} \mathrm{C}$, atingindo teor de água de, aproximadamente, $30 \%$. Metade das amostras de cada tratamento foi secada até atingir teor de água próximo ao inicial (7,2\%); em seguida, avaliou-se o desempenho das sementes condicionadas submetidas ao não à secagem, além de sementes não condicionadas (testemunha), quanto à germinação (porcentagem e velocidade) e o vigor (condutividade elétrica dos exudatos das sementes). A porcentagem e a velocidade de emergência de plântulas foram avaliadas em condições de casa de vegetação, enquanto que o comprimento de plântulas e a uniformidade de desenvolvimento das plântulas foram estimados usando o software de análise computadorizada de imagens de plântulas SVIS ${ }^{\circledR}$. As sementes condicionadas fisiologicamente apresentaram potencial fisiológico superior, demonstrado principalmente pelos resultados da análise de imagens. Assim, as sementes condicionadas em água durante 16 h ou em PEG durante 88 h, ambas não submetidas à secagem subsequente, e as condicionadas em PEG durante $56 \mathrm{~h}$ e submetidas a secagem, beneficiaram o desempenho germinativo de G. ulmifolia. Sugere-se que esses tratamentos são promissores para aumentar a eficiência de estabelecimento de estande dessa espécie via semeadura direta em programas de restauração ecológica.

Palavras-chave: SVIS ${ }^{\circledR}$, sementes florestais, vigor de sementes, restauração ecológica, semeadura direta
\end{abstract}

\section{Introduction}

Proliferation of invasive grasses is one of the primary problems faced during tropical forest restoration in degraded areas (Brancalion et al., 2009). Rapid soil shading by tree canopies must occur to reduce weeds and enhance the early growth of shade-tolerant trees. Pioneer trees have been traditionally used as fast-growing species to create a forest structure in a short period (2-3 years), reducing maintenance costs and increasing restoration effectiveness (Rodrigues et al., 2009). 
Lamb et al. (2005), Doust et al. (2006) and Ferreira et al. (2007) have supported the use of direct seeding as a promising procedure for forest restoration, stimulating research to improve this technique. Despite the successful use of pioneer species seedling in forest restoration efforts, direct seeding of such species may be affected by defective seed germination and seedling emergence.

Most pioneer species have dormant seeds, and priming could be an additional procedure to improve germination uniformity as already described for other Brazilian tree species (Brancalion et al., 2008; Perez and Jardim, 2005; Silva et al., 2005). Priming is a treatment of controlled seed hydration, in which the metabolic activity is enhanced, but suspended before primary root protrusion (Bradford, 1986; Heydecker et al., 1975). Upon priming condition removal, seed germination is usually faster and more uniform.

Priming efficiency was traditionally evaluated based on the intensity and rate of seed germination and seedling emergence. As automated computer image analysis systems were already successfully used as seed vigor test in several crop species (Hoffmaster et al., 2003; Marcos-Filho et al., 2009; Sako et al., 2001), these techniques were adopted in testing the potential of tree seeds' priming (Brancalion et al., 2008).

The aim of this research is to evaluate priming effectiveness in enhancing Guazuma ulmifolia Lam. (Malvaceae) germination performance, which may lead to an increase in direct seeding applicability as an ecological restoration tool.

\section{Material and Methods}

Species and seed harvesting: Guazuma ulmifolia Lam. (Malvaceae) is a pioneer tree species that grows in Central America (Janzen, 1982) and all of Latin America (Barbosa and Macedo, 1993), including the Semideciduous Seasonal Forests in Brazil, where it can be used for timber, cosmetical, medicinal, ornamental and edible purposes (Almeida et al., 1998). Moreover, this fast-growing species has been used in the ecological restoration of riverine forests (Lorenzi, 2002; Souza and Batista, 2004). As result of G. ulmifolia wide geographical and ecological distribution, this species is one of the most used in riverine forest restoration initiatives along tropical American forests. G. ulmifolia seeds were harvested in Piracicaba, state of São Paulo, Brazil (UTM 23k 0230003 - 7486288) from 16 wild mother trees, and used in the experiments three months after harvest. Seeds were kept under controlled storage conditions during these three months (paper bags, $15^{\circ} \mathrm{C}$ and $40 \%$ of air relative humidity).

Overcoming dormancy: Preliminary germination tests performed with fresh harvested seeds indicated $92 \%$ dormancy. Overcoming of seed hardness was accomplished before installing all experiments by immersing seeds in concentrated sulfuric acid for $50 \mathrm{~min}$ (Araújo Neto and
Aguiar, 2000); seeds were then washed in water (120 s) after acid treatment until the complete removal of acid residues.

Seed hydration curves to select priming treatments: To define the duration of priming treatments, seed hydration curves were previously determined under different water potentials. Initial seed moisture content was determined by the oven method (Brasil, 1992), with air circulation at $105^{\circ} \mathrm{C}$ for $24 \mathrm{~h}$. Seed moisture content was expressed on wet weight basis. Seed hydration curves were determined under the osmotic potentials of 0.0 , $0.4,-0.8$ and $-1.2 \mathrm{MPa}$ at $20^{\circ} \mathrm{C}$, with four replicates of 100 seeds for each potential. Deionized water was used for 0.0 MPa and PEG 8000 solutions, prepared according to Michel and Kaufmann (1973), for the other osmotic potentials. Seeds were placed on top of three round blotters $(7 \mathrm{~cm}$ diameter) soaked with $15 \mathrm{~mL}$ of water or PEG solutions in Petri dishes that were incubated in a chamber at $20^{\circ} \mathrm{C}$ under constant light. Seed hydration was evaluated every four hours during the first $24 \mathrm{~h}$, and every $12 \mathrm{~h}$ during the subsequent phase of seed hydration. Moisture content was monitored according to Cromarty et al. (1985). Seeds were dried on paper towels to remove free water from seed coat surface before weighting. The estimated final seed moisture content was compared to the oven method results to confirm the accuracy of procedures adopted for seed hydration.

Priming treatments: Seeds were primed at $20^{\circ} \mathrm{C}$ in water $(0.0 \mathrm{MPa})$ for $16 \mathrm{~h}$ or in PEG $8000(-0.8 \mathrm{MPa})$ for $56 \mathrm{~h}$ and $88 \mathrm{~h}$. To study the effects of drying back after priming, half of the primed seed samples was submitted to fast drying at $30^{\circ} \mathrm{C}$ with constant air flow, until the initial $7.2 \%$ seed moisture content was reached. In this way, seed drying was completed in three hours. Seven seed samples were tested: non-primed seeds; seeds primed in water for $16 \mathrm{~h}$, submitted or not to drying; seeds primed in PEG solution for 56 and $88 \mathrm{~h}$, submitted or not to drying.

Germination test: Seeds were sown between two moistened blue blotters $(20.0 \times 13.0 \mathrm{~cm})$, with one wax paper sheet between the blotters, which were placed in plastic boxes $(15 \times 23 \times 4 \mathrm{~cm}$, Model 600-C, Pioneer Packaging, Dixon, KY) and placed in a germination chamber at $25^{\circ} \mathrm{C}$, which is the best temperature for seed germination for this species (Araújo Neto et al., 2002). The boxes were kept in a near vertical orientation $\left(80^{\circ}\right.$ to $\left.85^{\circ}\right)$ to allow geotropic seedling growth. Seeds and seedlings remained in darkness as they were kept between blotters. Germination was scored daily to calculate germination percentage (Brasil, 1992) and germination rate index (Maguire, 1962).

Automated computer image analysis: Image acquisition was accomplished using the blotters and seedlings obtained from the germination test four days after planting by a custom scanning box computer system (Hoffmaster et al., 2003). The images were automatically processed by the Seedling Vigor Image System (SVIS ${ }^{\circledR}$ ) 
according to methodology described by Sako et al. (2001). This software automatically measures all seedlings but, as it was specifically developed for lettuce, G. ulmifolia seedlings were not always properly recognized and marked. In such situations, seedlings were manually corrected by appropriate software tools and automatically measured. Following individual seedling processing and automatic-manual measurements, the results of each replicate were combined to obtain seedling length and an index of uniformity of seedling development (Hoffmaster et al., 2003; Marcos-Filho et al., 2006; Marcos-Filho et al., 2009). Seedling length represents the total number of pixels per seedling, so it is essentially a length measurement of each seedling. Uniformity of seedling development included the penalty term in the uniformity algorithm to avoid the undesirable influence of dead seeds on the precision of the results. Results were expressed as mean values of seedling length (pixels) and uniformity of seedling development indices ranged from a minimum value of zero to a maximum of 1000 for each treatment.

Electrical conductivity of seed leachates: Seeds were weighted and immersed in beakers with $20 \mathrm{ml}$ of deionized water and kept in a chamber at $20^{\circ} \mathrm{C}$ for $24 \mathrm{~h}$. Measurements were carried out with the conductivimeter YSI 3100 (YSI Incorporated), and data were expressed in $\mu \mathrm{S} \mathrm{cm}^{-1} \mathrm{~g}^{-1}$.

Seedling emergence: Seeds were individually planted in multicell polystyrene trays (200 cells/tray), containing an artificial growing mixture. The trays were placed in greenhouse and subjected to intermittent spraying for irrigation. Seedling emergence was recorded daily to calculate emergence percentage and rate index (Maguire, 1962).

Statistical analysis: Four replicates of 25 seeds each were used in a completely randomized design in the germination test (percentage and rate index), automated image analysis (seedling length and uniformity of seedling length) and electrical conductivity of seed leachates. Eight replicates of 25 seeds each were used in a randomized blocks design for seedling emergence evaluation (emergence percentage and emergence rate index). Percentage data was transformed to $\operatorname{arc} \sin \sqrt{x / 100}$ and the multiple means comparison was performed using the Tukey's test $(\alpha=0.05)$.

\section{Results and Discussion}

Seed hygroscopic equilibrium occurred at lower seed moisture content in the more negative osmotic potentials (Figure 1). This reduction was enough to avoid primary root protrusion and keep seeds in phase II of water uptake (Bewley and Black, 1982). The lower water potential prevents the normal preparatory metabolism for complete germination, stabilizing hydration below the critical moisture content for primary root protrusion. This is a desirable situation for the definition of priming treatment conditions as seeds can be kept at the same moisture content for a longer period, enhancing cellular membrane repair and physiological processes that affect protein (González-Zertuche et al., 2001), enzyme (Nascimento et al., 2001), DNA (Ashraf and Bray, 1993) and RNA (Clarke and James, 2006) synthesis and activity.

Priming in water for $16 \mathrm{~h}$ and in PEG for 56 and 88 h enhanced G. ulmifolia seed performance (Table 1). Seed germination was higher in primed seeds, which also contributed to improve seed vigor as observed by higher values of germination rate index, seedling growth and uniformity of seedling growth, emergence percentage and emergence rate index, and lower values of electrical conductivity of seed leachates. Testing direct seeding of pioneer native species, Santos Júnior et al. (2004) obtained the lowest percentages of seedling emergence for Guazuma ulmifolia Lam. seeds due to seed hardness and lack of germination uniformity. This might be associated to the natural behavior of this species in forests, since seeds may remain in a seed bank waiting for gaps (Motta et al., 2006). Thus, priming and seed scarification could be an effective G. ulmifolia pretreatment to achieve higher seedling emergence uniformity after direct seeding.

The evaluation of germination physiological parameters supplies important experimental evidences to indicate priming and seed scarification as important tools to enhance direct seeding effectiveness and also to improve seedling production for restoration ecology, as demonstrated for greenhouse experiments. Despite seed priming for $88 \mathrm{~h}$ in PEG solution has been one of the best treatments, SVIS ${ }^{\circledR}$ analysis demonstrated that seed enhancement was reduced after seed drying. As a result, G. ulmifolia priming for $88 \mathrm{~h}$ is effective only if seeds

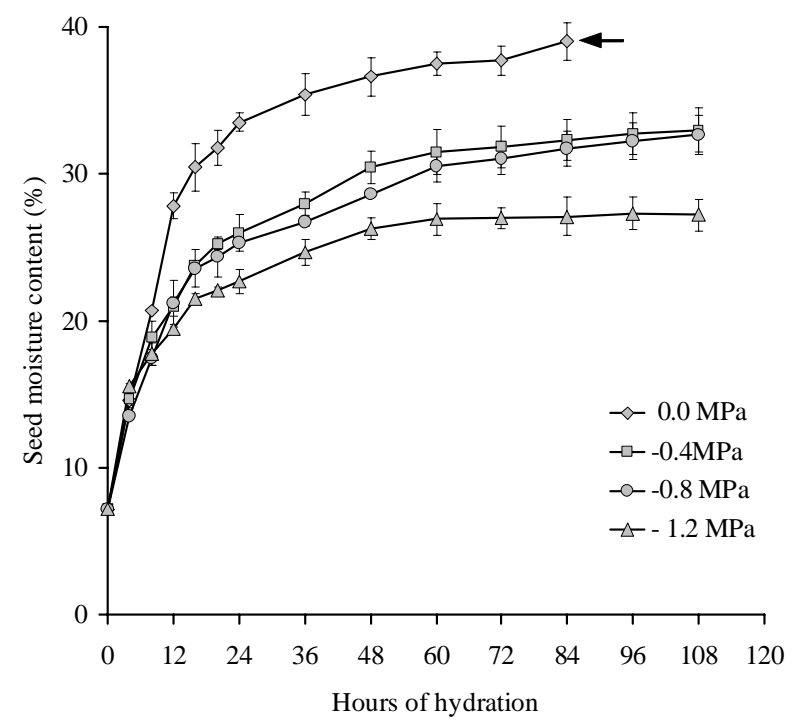

Figure 1 - Hydration curves of Guazuma ulmifolia Lam. seeds in deionized water $(0.0 \mathrm{MPa})$ and in aqueous PEG 8000 solutions $(-0.4,-0.8$ and $-1.2 \mathrm{MPa})$ at $20^{\circ} \mathrm{C}$. $(\leftarrow$ indicates time of primary root protrusion; vertical lines represent the standard deviation). 
Table 1 - Effects of seed priming treatments following acid scarification on the germination performance of Guazuma ulmifolia seeds. Germination (G) percentage, germination rate index (GRI), seedling length, uniformity of seedling development (SVIS ${ }^{\circledR}$ index), electrical conductivity of seed leachates (E.C.), percentage seedling emergence $(\mathrm{E})$ and emergence rate index (ERI).

\begin{tabular}{|c|c|c|c|c|c|c|c|}
\hline Treatment & G & GRI & length & uniformity & E.C. & E & ERI \\
\hline & $\%$ & & Pixels & & 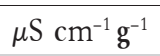 & $\%$ & \\
\hline non-primed seeds & $70 \mathrm{~b}$ & $12.7 \mathrm{~b}$ & $276 \mathrm{c}$ & $31 \mathrm{c}$ & $54.4 \mathrm{a}$ & $45 \mathrm{~b}$ & $2.4 \mathrm{~b}$ \\
\hline water fresh & $82 \mathrm{ab}$ & $15.7 \mathrm{ab}$ & $387 \mathrm{ab}$ & $98 \mathrm{bc}$ & $33.1 \mathrm{c}$ & $71 \mathrm{a}$ & $4.6 \mathrm{a}$ \\
\hline water dried & $73 \mathrm{ab}$ & $14.0 \mathrm{ab}$ & $317 \mathrm{bc}$ & $24 \mathrm{c}$ & $29.8 \mathrm{c}$ & $58 \mathrm{ab}$ & $3.6 \mathrm{ab}$ \\
\hline PEG 56h fresh & 91 a & $17.7 \mathrm{a}$ & 391 a & $183 \mathrm{ab}$ & $30.7 \mathrm{c}$ & $62 \mathrm{ab}$ & $4.2 \mathrm{a}$ \\
\hline PEG 56h dried & $77 \mathrm{ab}$ & $15.0 \mathrm{ab}$ & $362 \mathrm{ab}$ & $129 \mathrm{ab}$ & $40.3 \mathrm{~b}$ & $60 \mathrm{ab}$ & $3.6 \mathrm{ab}$ \\
\hline PEG $88 \mathrm{~h}$ fresh & $90 \mathrm{a}$ & $17.7 \mathrm{a}$ & 399 a & 256 a & $34.2 \mathrm{c}$ & $60 \mathrm{ab}$ & $4.4 \mathrm{a}$ \\
\hline PEG $88 \mathrm{~h}$ dried & $61 \mathrm{~b}$ & $11.7 \mathrm{~b}$ & $275 c$ & $21 \mathrm{c}$ & $39.9 \mathrm{~b}$ & $48 \mathrm{~b}$ & $3.2 \mathrm{ab}$ \\
\hline $\mathrm{CV}^{*}(\%)$ & 10.1 & 11.6 & 9.0 & 58.3 & 6.1 & 10.7 & 22.5 \\
\hline
\end{tabular}

*Means within a column followed by the same letter were not different (Tukey test, $p>0.05$ ). CV - coefficient of variation.

are sowed immediately after priming and during periods when soil water availability does not limit germination.

Benefits obtained by priming may be partially or entirely reverted after seed drying (Carpenter, 1989; Parera and Cantilife, 1992), possibly due to reduced oligosaccharide concentration in cells, which diminishes cytoplasm viscosity and increases seed susceptibility to deterioration processes (Buitink et al., 2000). These findings were confirmed by other authors that showed increased drying sensitivity of seeds primed for longer periods that were submitted to accelerated aging (Chojnowski et al., 1997). However, the conditions used to dry back seeds after priming has a remarkable importance to avoid physiological deterioration (Butler et al., 2009), as demonstrated in primed and dried seeds which can retain priming benefits (Barbedo et al., 1997; Kikuti and Marcos-Filho, 2008).

Uniformity of seedling development showed a wide range of variation among priming treatments, suggesting that the sensitivity of this parameter is related to seed treatment and is related to the assessment by the image analysis technique. Although the accuracy of automated image processing had already been shown for lettuce (Sako et al., 2001), soybean (Hoffmaster et al., 2003) and melon (Marcos-Filho et al., 2006), this system has just recently been used to analyze tree seeds (Brancalion et al., 2008). Based on the results obtained here, this technique has high potential to be used with other native species, giving a new perspective for seed analysis of this type of seeds. However, uniformity of seedling growth values ranged widely, resulting in a high coefficient of variation $(58.3 \%)$. High coefficients of variation were also found in other studies on native tree species (Brancalion et al., 2009), which suggested that natural genetic heterogeneity has to be considered when planning experimental designs to work with tree species.

Uniformity of seedling development was more affected by treatments than the germination rate index, which can be considered as a germination uniformity parameter by priming treatments. This suggested that seedling development after primary root protrusion may also be an additional factor of heterogeneity, despite irregular germination, to increase the non-uniformity of seedling development. Uniformity of seedling length is a useful and reliable measure of seed vigor, allowing the comparison of different seed lots treated by priming, and its evaluation by SVIS $^{\circledR}$ may have also and additional value in seed performance analysis. As priming has traditionally been considered an effective treatment to enhance cellular membrane repair mechanisms in seeds, electrical conductivity of seed leachates is an important evaluation of priming treatment effectiveness. Electrical conductivity of seed leachates was reduced in primed seeds, especially in those not submitted to drying. Lower values of electrical conductivity indicated that cellular membranes were correctly reorganized during hydration. If repair mechanisms of seed membranes work properly, seed leachates are reduced and the electrical conductivity readings become lower (Copeland and McDonald, 2001).

Priming may also reduce the level of imbibition injuries during rapid water absorption by seeds, since the process is slower under low water osmotic potentials. However, Copeland and McDonald (2001) suggested that part of seed solutes is washed off during priming, thus reducing the amount of solutes that interfered with the electrical conductivity analysis. As a result, electrical conductivity of seed leachates seemed to be more related to the washing off of seed solutes during priming than to the increase of seed vigor. Electrical conductivity of seed leachates from PEG primed seeds submitted to drying was higher when compared with fresh primed seeds. This could be due to the occurrence of mechanical damage during seed drying, as previously reported for Pinus sylvestris and Larix gmelinii seeds (Huang and Zou, 1989), and for soybean seeds (Armstrong and McDonald, 1992), or to the expected disorganization of cellular membranes following drying. 
Results from this study indicated priming effectiveness to enhance seed performance in pioneer trees and could also be promising for other native tree species. Moreover, priming may be even more efficient in native species which do not have hardseededness, although priming may also improve germination in hard-seeded species (Tonini et al., 2005). As seed moisture content and subsequent deterioration may increase during the storage of non-dormant seeds if environmental conditions are not ideal (as present in most companies of tree seed production) the range of physiological potential differences among seed lots may be reduced by priming, allowing a higher seedling emergence uniformity after direct seeding.

In conclusion, treatments in water for $16 \mathrm{~h}$ and in PEG $(-0.8 \mathrm{MPa})$ for $56 \mathrm{~h}$ with or without drying or in PEG for $88 \mathrm{~h}$ without drying improve G. ulmifolia seed germination performance and may be considered as a promising procedure to enhance the efficiency of stand establishment by direct seeding of this species in restoration ecology programs.

\section{Acknowledgements}

To Dr. Mark Bennett for helpful suggestions to improve English style and scientific content, and also to the three anonymous reviewers for useful comments to the manuscript. CNPq is acknowledged for financial support.

\section{References}

Almeida, S.P.; Proença, C.E.B.; Sano, S.M.; Ribeiro, J.F. 1998. Cerrado: Espécies Vegetais Úteis. EMBRAPA/CPAC, Brasília, DF, Brazil.

Araújo Neto, J.C.; Aguiar, I.B. 2000. Germinative pretreatments to dormancy break in Guazuma umlifolia Lam. seeds. Scientia Forestalis 58: 15-24.

Araújo Neto, J.C.; Aguiar, I.B.; Ferreira, V.M.; Rodrigues, T.J.D. 2002. Cardinal temperatures and effect of light on Guazuma ulmifolia Lam. seed germination. Revista Brasileira de Engenharia Agrícola e Ambiental 6:460-465 (in Portuguese, with abstract in English).

Armstrong, H.; McDonald, M.B. 1992. Effects of osmoconditioning on water uptake and electrical conductivity in soybean seeds. Seed Science and Technology 20: 391-400.

Ashraf, M.; Bray, C.M. 1993. DNA synthesis in osmoprimed leek (Allium porrum L.) seeds and evidence for repair and replication. Seed Science Research 3:15-23.

Barbedo, C.J.; Marcos-Filho, J.; Novembre, A.D.L.C. 1997. Osmoconditioning and storage of Cedrela fissilis Vell. seeds. Revista Brasileira de Sementes 19: 355-361 (in Portuguese, with abstract in English).

Barbosa, J.M.; Macedo, A.C. 1993. Essências Florestais Nativas de Ocorrência no Estado de São Paulo: Informações Técnicas sobre Sementes, Grupos Ecológicos, Fenologia e Produção de Mudas. Instituto de Botânica e Fundação Florestal, São Paulo, SP, Brazil.

Bewley, J.D.; Black, M. 1982. Physiology and Biochemistry of Seeds in Relation to Germination. Springer-Verlag, Berlin, BE, Germany.

Bradford, K.J. 1986. Manipulation of seed water relations via osmotic priming to improve germination under stress conditions. HortScience 21: 1105-1112.
Brancalion, P.H.S.; Novembre, A.D.L.C.; Rodrigues, R.R.; Tay, D. 2008. Priming of Mimosa bimucronata seeds: a tropical tree species from Brazil. Acta Horticulturae 782: 163-168.

Brancalion, P.H.S.; Isernhagen, I.; Machado, R.P.; Christoffoleti, P.J.; Rodrigues, R.R. 2009. Selectivity of the herbicides sethoxydim, isoxaflutole and bentazon on native tree species. Pesquisa Agropecuária Brasileira 44: 251-257 (in Portuguese, with abstract in English).

Brasil. Ministério da Agricultura e Reforma Agrária. 1992. Regras para a Análise de Sementes. SNDA/DNDV/CLAV, Brasília, DF, Brazil.

Buitink, J.; Hoekstra, F.A.; Hemminga, M.A. 2000. A critical assessment of the role of oligosaccharides in intracellular glass stability. p. 461-466. In: Black, M.; Bradford, K.J.; VázquezRamos, J., eds. Seed biology: advances and applications. CABI, Wallingford, UK.

Butler, L.H.; Hay, F.R.; Ellis, R.H.; Smith, R.D.; Murray, T.B. 2009. Priming and re-drying improve the survival of mature seeds of Digitalis purpurea during storage. Annals of Botany 103: 1261-1260.

Carpenter, W.J. 1989. Salvia splendens seed pregermination and priming for rapid and uniform emergence. Journal of the American Society of Horticultural Science 114: 247-250.

Chojnowski, M.; Corbineau, F.; Côme, D. 1997. Physiological and biochemical changes induced in sunflower seeds by osmopriming and subsequent drying, storage and aging. Seed Science Research 7: 323-332.

Clarke, N.A.; James, P.E. 2006. The effects of priming and accelerated ageing upon the nucleic acid content of leek seeds and their embryos. Journal of Experimental Botany 42: 261-168.

Copeland, L.O.; McDonald, M.B. 2001. Principles of Seed Science and Technology. 4 ed. Springer, New York, NY, USA.

Cromarty, A.S.; Ellis, R.H.; Roberts, E.H. 1985. Design of Seed Storage Facilities for Genetic Conservation. IPGRI, Rome, RO, Italy.

Doust, S.J.; Erskine, P.D.; Lamb, D. 2006. Direct seeding to restore rainforest species: microsite effects on the early establishment and growth of rainforest tree seedlings on degradated land in the wet tropics of Australia. Forest Ecology and Management 234: 333-343.

Ferreira, R.A.; Davide, A.C.; Bearzoti, E.; Motta, M.S. 2007. Tree species direct sowing for forest restoration. Cerne 13: 271-279 (in Portuguese, with abstract in English).

González-Zertuche, L.; Vázquez-Yanes, C.; Gamboa, A.; SánchezCoronado, M.E.; Aguilera, P.; Orozco-Segovia, A. 2001. Natural priming of Wigandia urens seeds during burial: effects on germination, growth and protein expression. Seed Science Research 11: 27-34.

Heydecker, M.; Higgins, J.; Turner, Y.J. 1975. Invigoration of seeds? Seed Science and Technology 3: 881-888.

Hoffmaster, A.L.; Fujimura, K.; McDonald, M.B.; Bennett, M.A. 2003. An automated system for vigor testing three-day-old soybean seedlings. Seed Science and Technology 31: 701-713.

Huang, Y.G.; Zou, Q. 1989. Effect of osmoconditioning and drying on germination of Pinus sylvestris var. Mongloica and Larix gmelinii seeds. Seed Science and Technology 17: 235-242.

Janzen, D.J. 1982. Natural history of guacimo fruits (Sterculiaceae: Guazuma ulmifolia) with respect to consumption by large mammals. American Journal of Botany 69: 1240-1250.

Kikuti, A.L.P.; Marcos-Filho, J. 2008. Drying and storage of cauliflower hydroprimed seeds. Seed Science and Technology 36: 396-406.

Lamb, D.; Erskine, P.D.; Parrota, J.A. 2005. Restoration of degradated tropical forest landscapes. Science 310: 1628-1632.

Lorenzi, H. 2002. Árvores Brasileiras: Manual de Identificação e Cultivo de Plantas Arbóreas do Brasil. v2. Instituto Plantarum, Nova Odessa, SP, Brazil.

Maguire, J.D. 1962. Rates of germination aid selection and evaluation for seedling emergence and vigor. Crop Science 2: 176-177. 
Marcos-Filho, J.M.; Bennett, M.A.; McDonald, M.B.; Evans, A.F.; Grassbaugh, E.M. 2006. Assessment of melon seed vigour by an automated computer imaging system compared to traditional procedures. Seed Science and Technology 34: 485-497.

Marcos-Filho, J.M.; Kikuti, A.L.P.; Lima, L.B. 2009. Procedures for evaluation of soybean seed vigor, including an automated computer imaging system. Revista Brasileira de Sementes 31: 102-112 (in Portuguese, with abstract in English).

Michel, B.E.; Kaufmann, M.R. 1973. The osmotic potential of polyethylene glycol 6000. Plant Physiology 51: 914-916.

Motta, M.S.; Davide, A.C.; Ferreira, R.A. 2006. Seed longevity of mutamba (Guazuma ulmifolia Lam. - Sterculiaceae) in the soil under natural conditions. Revista Brasileira de Sementes 28: 714 (in Portuguese, with abstract in English).

Nascimento, W.M.; Cantliffe, D.J.; Huber, D.J. 2001. Endo-âmannanase activity and seed germination of thermosensitive and thermotolerant lettuce genotypes in response to seed priming. Seed Science Research 11: 255-264.

Parera, C.A.; Cantliffe, D.J. 1992. Enhanced emergence and seedling vigor in shrunken-2 sweet corn by seed disinfection and solid matrix priming. Journal of the American Society of Horticultural Science 117: 400-403.

Perez, S.C.J.G.A.; Jardim, M.M. 2005. Viability and vigor in folk silk tree seeds after storage, conditioning and submission to salt and thermal stress. Pesquisa Agropecuária Brasileira 40: 587-593 (in Portuguese, with abstract in English).

Rodrigues, R.R.; Lima, R.A.F.; Gandolfi, S.; Nave, A.G. 2009. On the restoration of high diversity forests: 30 years of experience in the Brazilian Atlantic Forest. Biological Conservation 142: 1242-1251.
Sako, Y.; McDonald, M.; Fujimura, K.; Evans, A.; Bennett, M. 2001. A system for automated seed vigor assessment. Seed Science and Technology 29: 625-636.

Santos Júnior, N.A.; Botelho, S.A.; Davide, A.C. 2004. Study of germination and survival of three species in direct seeding system, aiming riparian forest restoration. Cerne 10: 103-117 (in Portuguese, with abstract in English).

Silva, L.M.M.; Aguiar, I.B.; Morais, D.L.; Viégas, R.A. 2005. Water stress and osmotic conditioning on physiological quality of Cnidosculus juercifolius Pax \& K. Hoffam seeds. Revista Brasileira de Engenharia Agrícola e Ambiental 9: 66-72 (in Portuguese, with abstract in English).

Souza, F.M.; Batista, J.L.F. 2004. Restoration of seasonal semideciduous forests in Brazil: influence of age and restoration design on forest structure. Forest Ecology and Management 191: 185-200.

Tonini, G.A.; Gatti, A.B.; Carelli, B.P.; Perez, S.C.J.G.A. 2005. Priming temperature effects on viability and vigor of Pterogyne nitens Tull seeds. Revista Brasileira de Sementes 27: 35-43 (in Portuguese, with abstract in English).

Received December 19, 2008

Accepted January 05, 2010 